\title{
TERRITORIAL IDENTIFICATION OF THE CHINGAZA NATIONAL NATURAL PARK IN THE SAN JUANITO META MUNICIPALITY \\ CASTRO GARZÓN HERNANDO ${ }^{1}$, RODRÍGUEZ MIRANDA JUAN PABLO ${ }^{2} \&$ RIVAS TRUJILLO EDWIN $^{3}$
}

${ }^{\text {I}}$ Profesor. Escuela de Administración y Negocios. Facultad de Ciencias Económicas, Universidad de los Llanos, Villavicencio, Colombia

${ }^{2}$ Profesor Titular. Facultad del Medio Ambiente y Recursos Naturales. Universidad Distrital Francisco José de Caldas. Bogotá, Colombia

${ }^{3}$ Grupo de Investigación Interferencia Electromagnética (GCEM), Ingeniería Eléctrica, Facultad de Ingeniería, Universidad Distrital Francisco José de Caldas, Cra 7 No 40B-53, Bogotá, Colombia

\begin{abstract}
Protected areas in Colombia began their establishment before the 1991 Constitution where community participation is safeguarded for their declaration. Preceding it, the conformation of the Chingaza National Park impacts the communities established in these territories for a century; being a generator of conflict for the owners or possessors of these properties and pressure for the conservation of the National Natural Park. The San Juanito municipality is inserted into area of the Park the 50\% of its territory and due to its outstanding orographic conditions, as well as watershed management plans, which further increase the proportion of restricted use areas.

This work documented the property composition of the portion of the Chingaza National Park corresponding to the San Juanito municipality. Techniques were used to collect information such as observation, cartographic documentation and interviews with experts. Once the study area was determined, the field was approached, classified by sidewalks and visiting each of the cadastral identified properties. The influence of these settlements in the protection zone was verified, determined in a number of 58 properties in total, presenting the highest concentration of properties in the San Luis de Toledo and Candelaria villages, respectively.

KEYWORDS: Protected Areas, Sustainability, Community, Farms, Territory
\end{abstract}

Received: Jun 08, 2020; Accepted: Jun 28, 2020; Published: Sep 25, 2020; Paper Id.: IJMPERDJUN20201424

\section{INTRODUCTION}

The conservation of strategic areas for the countries has been structured as a policy in their development plans (Vergara \& Albornoz 2019). These schemes have been widely disseminated in emerging countries, causing sudden changes in the dynamics of the peasant communities that occupy these territories, due to the restrictions on land use and resources present in these areas (Rauch et al, 2019). The effects of the declaration of Protected Areas (AP) reflected in benefits for ecosystems but negatively impact communities living there (Orgaz, 2018) leading to question the model conservation proposed. In Colombia, AP are structured and administered by the National System of Protected Areas (SINAP), determining 59 in the national territory (Vásquez M \& Andrade, 2016); the use and enjoyment of territories delimited in them is restricted and determined by the law (Ponce de León, 2019) establishing the unique role of conservation within the protected areas (Parques Nacionales Naturales de 
Colombia, 2015) set up limitations for stocks established in these areas in the development of their economic, cultural and social activities. So, you need different set criteria for the settle of AP's by the administrations via minimal impact to the population, allowing develop strategies for involvement of agents and actors approaching conservation policies and the rural development (Mendigorri, 2017).

This work tries to show in terms of territory the influence of the peasant communities in the APs, verifying their insertion in the Chingaza National Park from a characterization of the rural area.

\section{MATERIALS AND METHODS}

In order to have a perspective of the territory under study, a series of descriptors was generated, based on cartographic and property information, in order to identify them and determine their inclusion in the area of influence analyzed based on descriptive research (Ávila, 2019) that allowed exposing the characteristics of the area by locating the properties inserted in the AP area, making the property characterization for each sidewalk present in the study zone.

\subsection{Venue Description}

The municipality presents a total of 677 properties (Alcaldía San Juanito, 2016); it is clarified that the properties present breakdowns and de facto holdings that create a greater number of them (EOT, 2005). Those who are present in the following neighborhoods: San Luis de Toledo, San Luis El Plan, La Candelaria, El Carmen, San Roque, San Juanito (Centro), El Tablon, San José and Los Rubios Alcaldía San Juanito-Meta, 2017; SIG Unillanos ${ }^{1}$, 2017). The protected areas under study are those of the Páramo De Chingaza, defined in Resolution 710 of 2016 and the Chingaza National Natural Park (PNNCH), erected as a National Natural Park through Resolution 154 of June 1977 and Decree 622 of 1977 regulation and the 2811 of 1974 that establishes the system of National Parks.

Within the exercise of overlap and mapping, a disparity was detected as to the jurisdiction of the Environmental Corporation, CORMACARENA, in the San Roque village, and in their maps wilderness area is located; when doing the respective thing with the map generated by PNNCH the jurisdiction of CORMACARENA disappears and it happens to the National Park. The other districts, except Los Rubios, present partial inclusion in different proportions in the PNNCH area.

The eastern and northeastern areas are mostly comprised of the paths of El Tablon and San Roque that only have one single property each, which are the property of the nation (IGAC-Instituto Geográfico Agustín Codazzi, 2017). In the northern part of the municipality there are the paths of San Luis El Plan and San Luis de Toledo; The latter has the largest extension inserted in protection zones (SIG Unillanos, 2017). The western zone includes the paths of San Juanito (center), El Carmen and La Candelaria; in these sidewalks the highest concentration of properties can be seen (SIG Unillanos, 2017). Finally, the south-western area comprised by the San José sidewalk has only two properties, partially inserted within the park area, although one in a greater proportion than the other (SIG Unillanos, 2017); The number of properties in the study area is 58 with an extension ranging from 1.7 to 4,609 hectares (SIG Unillanos, 2017).

\section{RESULTS}

Vereda San Luis El Plan. It has nine (9) properties entered in a protection zone: three (3) in total way and six (6)

\footnotetext{
${ }^{1}$ Sistema de Información Geográfica de la Universidad de los Llanos
} 
partially; There are farms with extensions less than 100 ha, with three (3) less than 50 ha, five (5) greater than 50 ha, with the exception of one greater than 2,000 ha; presents two legalized owners.

Table 1: Owners- San Luis El Plan Lane

\begin{tabular}{|c|c|c|c|c|c|}
\hline Cadastral certificate & PNN Owner & IGAC Owner & Area & Coverage & Enrollment \\
\hline 100040037000 & SL 001 & SL 001 & 64,9808612 & Partial & 20102610037171000 \\
\hline 100040038000 & SL002 & SL002 & 95.00261587 & Partial & Not \\
\hline 100040039000 & SL003 & SL0031 & 24.43127606 & Total & Not \\
\hline 100040041000 & SL004 & SL004 & 86,66889919 & Total & $230-34061$ \\
\hline 100040042000 & SL005 & SL005 & 55,99892578 & Partial & Not \\
\hline 100040043000 & SL006 & SL006 & 22,19682879 & Partial & Not \\
\hline 100040053000 & SL007 & Nation & 2627,199385 & Partial & Not \\
\hline 100040055000 & SL008 & SL008 & 24.57176553 & Total & Not \\
\hline 100040056000 & Nation & SL0092 & 59,1002318 & Partial & Not \\
\hline
\end{tabular}

Source: IGAC 2017, PNNCH 2017, SIG2017. Adapted by the author.

Sidewalk San Luis de Toledo: It has twenty (20) properties in the protection zone, thirteen (13) in total way and seven (7) partially; Presenting 16 properties under 50 ha, two (2) over 50 ha, one (1) over 4,000 ha and one (1) does not register an area or owner; none have Real Estate Registration.

Table 2: Owners San Luis de Toledo Lane

\begin{tabular}{|c|c|c|c|c|c|}
\hline Cadastral certificate & PNN Owner & IGAC Owner & Area & Coverage & Enrollment \\
\hline 50686000100030059000 & ST010 & ST010 & 12.1 & Total & No \\
\hline 50686000100030060000 & SP11 & ST11 & 22.6 & Total & No \\
\hline 50686000100030058000 & ST12 & ST12 & 16.6 & Total & No \\
\hline 50686000100030057000 & ST13 & ST13 & 15.2 & Total & No \\
\hline 50686000100030061000 & ST14 & ST143 & 16.6 & Total & No \\
\hline 50686000100030063000 & ST15 & ST15 & 20.7 & Total & No \\
\hline 50686000100030062000 & ST16 & ST16 & 26 & Total & No \\
\hline $01-03-0081$ & Does not register & Does not register & N / a & Partial & \\
\hline 50686000100030053000 & ST18 & ST18 & 58.4 & Total & \\
\hline
\end{tabular}




\begin{tabular}{|c|c|c|c|c|c|}
\hline 50686000100030052000 & ST19 & ST19 & 31.3 & Total & No \\
\hline 50686000100030054000 & ST20 & ST20 & 36.5 & Total & No \\
\hline 50686000100030055000 & ST21 & ST21 & 10.3 & Total & No \\
\hline 50686000100030056000 & ST22 & ST22 & 12.8 & Partial & No \\
\hline 50686000100030045000 & ST23 & ST23 & 39.8 & Partial & No \\
\hline 50686000100030047000 & ST24 & ST24 & 57.4 & Partial & No \\
\hline 50686000100030048000 & ST25 & ST25 & 19.9 & Partial & No \\
\hline 50686000100030049000 & ST26 & ST26 & 23.4 & Total & No \\
\hline 50686000100030050000 & ST27 & ST27 & 16.9 & Total & No \\
\hline 50686000100030040000 & ST28 & ST28 & 25.3 & Partial & No \\
\hline 50686000100030080000 & ST29 & Nation & 4608.5 & Partial & \\
\hline
\end{tabular}

Source: IGAC 2017, PNNCH 2017, SIG 2017. Adapted by the author.

Sidewalk San Juanito Centro: Only one property is partially presented in the protection zone with an extension greater than 1000 ha.

Table 3: Owners- San Juanito -Centro Lane

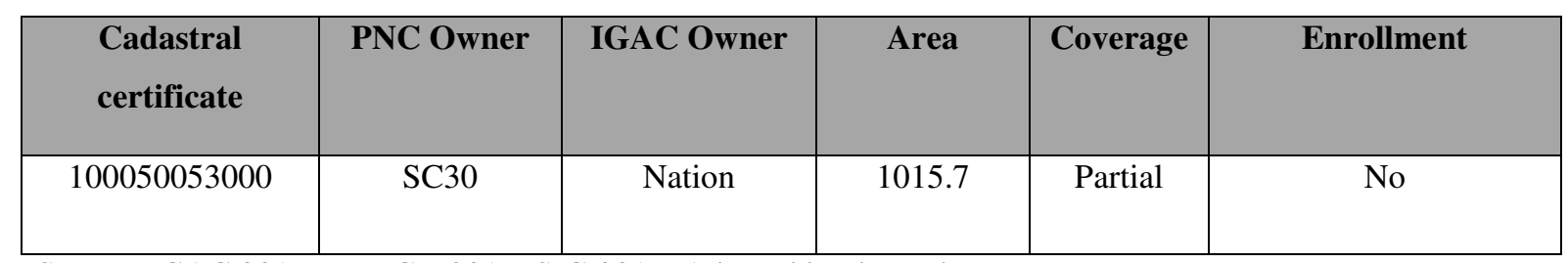

Source: IGAC 2017, PNNCH 2017, SIG 2017. Adapted by the author.

Vereda el Carmen: It has four (4) properties in a protection zone, two (2) partially and two (2) totally; being three (3) of less than 20 hectares and one of more than 900 ha; owns a legal estate.

Table 4: Owners- El Carmen Lane

\begin{tabular}{|c|c|c|c|c|c|}
\hline $\begin{array}{c}\text { Cadastral } \\
\text { certificate }\end{array}$ & PNC Owner & IGAC Owner & Area & Coverage & Enrollment \\
\hline 100060001000 & C31 & C 31 & 3,77024369 & Total & No \\
\hline 100060002000 & C32 & C32 & 923,022271 & Total & No \\
\hline
\end{tabular}




\begin{tabular}{|c|c|c|c|c|c|}
\hline 100060003000 & C33 & C33 & 17,8583378 & Partial & 102014000399650000 \\
\hline 100060084000 & C34 & Nation & 7,71634701 & Partial & No \\
\hline
\end{tabular}

Source: IGAC 2017, PNNCH 2017, SIG 2017. Adapted by the author.

La Candelaria Sidewalk: It has 20 properties, which 15 are partially inserted in a protection zone and five (5), in their entirety; it presents two (2) farms of more than 50ha, one (1) of more than 600 ha and 13 less than 50 ha; also two legalized properties.

Table 5: Owners- La Candelaria Lane

\begin{tabular}{|c|c|c|c|c|c|}
\hline Cadastral certificate & PNN Owner & IGAC Owner & Area & Coverage & $\begin{array}{c}\text { Real } \\
\text { estate registration }\end{array}$ \\
\hline 50686000100070137000 & CA35 & Nation & 662.9 & Partial & \\
\hline 50686000100070206000 & $\mathrm{~N} / \mathrm{A}$ & CA364 & 2.8 & Partial & No \\
\hline 50686000100070207000 & CA37 & CA37 & 10.2 & Partial & No \\
\hline 50686000100070143000 & CA38 & CA38 & 30.4 & Partial & No \\
\hline 50686000100070141000 & CA39 & CA39 & 7.2 & Partial & No \\
\hline 50686000100070024000 & CA40 & CA40 & 23.5 & Partial & No \\
\hline 50686000100070025000 & CA41 & CA41 & 24.2 & Total & No \\
\hline 50686000100070021000 & CA42 & CA42 & 19.4 & Total & No \\
\hline 50686000100070023000 & CA43 & CA43 & 35.7 & Partial & No \\
\hline 50686000100070221000 & CA44 & CA44 & 4.2 & Partial & No \\
\hline 50686000100070027000 & CA45 & CA45 & 51.1 & Partial & No \\
\hline 50686000100070028000 & CA46 & CA46 & 11.6 & Total & No \\
\hline 50686000100070020000 & CA47 & CA47 & 7.5 & Partial & No \\
\hline 50686000100070019000 & CA48 & CA48 & 11.7 & Total & No \\
\hline 50686000100070205000 & CA49 & CA49 & 31.4 & Partial & No \\
\hline 50686000100070152000 & $\mathrm{~N} / \mathrm{A}$ & CA505 & 178 & Partial & $230-59670$ \\
\hline 50686000100070010000 & CA51 & CA51 & 37.9 & Partial & 102021701024740000 \\
\hline
\end{tabular}




\begin{tabular}{|l|c|c|c|c|c|}
\hline 50686000100070214000 & CA52 & CA52 & 5.4 & Partial & No \\
\hline 50686000100070014000 & CA53 & CA53 & 22.3 & Partial & No \\
\hline 50686000100070006000 & CA54 & CA54 & 7.9 & Total & No \\
\hline
\end{tabular}

Source: IGAC 2017, PNNCH 2017, SIG 2017. Adapted by the author.

Sidewalk San José: It has two (2) partially inserted properties, one with less than 50 ha and the other with more than 400 ha; none have Real Estate Registration.

Table 6: Owners- San José Lane

\begin{tabular}{|c|c|c|c|c|c|}
\hline $\begin{array}{c}\text { Cadastral } \\
\text { certificate }\end{array}$ & PNC Owner & IGAC Owner & Area & Coverage & Enrollment \\
\hline 100080004000 & SJ55 & SJ55 & 32,6026764 & Partial & No \\
\hline 100080097000 & SJ56 & SJ56 & 414,297447 & Partial & No \\
\hline
\end{tabular}

Source: IGAC 2017, PNNCH 2017, SIG 2017. Adapted by the author.

San Roque sidewalk: It has a partially inserted property with an area greater than 1000 ha.

Table 7: Owners- San Roque Lane

\begin{tabular}{|c|c|c|c|c|c|}
\hline $\begin{array}{c}\text { Cadastral } \\
\text { certificate }\end{array}$ & PNC Owner & IGAC Owner & Area & Coverage & Enrollment \\
\hline 100010028000 & SR57 & Nation & 1606,24013 & Partial & No \\
\hline
\end{tabular}

Source: IGAC 2017, PNNCH 2017, SIG 2017. Adapted by the author.

Sidewalk el Tablón: A property appears partially covering half of the path in an area greater than 3,000 ha.

Table 8: Owners- El Tablon Lane

\begin{tabular}{|c|c|c|c|c|c|}
\hline $\begin{array}{c}\text { Cadastral } \\
\text { certificate }\end{array}$ & PNC Owner & IGAC Owner & Area & Coverage & Enrollment \\
\hline $\mathbf{1 0 0 0 2 0 0 5 2 0 0 0}$ & T58 & Nation & $\mathbf{3 2 0 7 . 2 1 1 0 2}$ & Partial & Not \\
\hline
\end{tabular}

Source: IGAC 2017, PNNCH 2017, SIG 2017. Adapted by the author.

\section{DISCUSSIONS}

Advancing in rationing, the farms are mostly less than 50 ha (Fernández-Zamudio, Caballero \& De Miguel, 2006, p. 197) 40 of 58 in total; hence the highest concentration is in the San Luis de Toledo district 16 and Candelaria 13 respectively; nine (9) farms larger than 50 ha are presented, with the highest concentration in the San Luis el Plan village and eight (8) large farms are presented (Olea P., 2017, p.100) between 400 and 4,600 ha. , distributed by each sidewalk; It is highlighted that five (5) of the largest properties appear under the same name, although they are now properties of the 
nation and in total seven (7) belong to it; In addition to the analyzed properties, only five (5) have Real Estate Registration, located two (2) in the La Candelaria sidewalk, one (1) in the El Carmen sidewalk and two (2) in the San Luis el Plan sidewalk; A property was found in the San Luis de Toledo district that does not present any record.

\section{CONCLUSIONS}

The properties located in the PNNCH area in $90 \%$ have only a tenure tradition, this being a disadvantage in case of negotiation for the eviction of the same; the farms present on the premises are solely for ranching and extensive pastures without the presence of permanent homes, temporary establishments or warehouses. The exploitations carried out in these estates are exclusively for determination of tenure, they are not subsistence or of continuous agricultural extraction. Some owners or tenants are unaware of the limits of the PAs considering that the PNNCH border is modified. $100 \%$ of the owners or tenants of the properties have two or more properties in different places that are not in areas of productive exclusion concluding that do not derive their main income from properties located in the territory of the Park.

\section{REFERENCES}

1. Alcaldía San Juanito - Meta. (2017). http://www.sanjuanito-meta.gov.col

2. Alcaldía de San Juanito. (2016). Informe poblacional base 2005. Página Oficial del Municipio. http://www.sanjuanitometa.gov.co/index.shtml

3. Ávila, A. J. M., Suarez, A. K. B., Pacheco-Martínez, Z. K., Gonzaga, J. A. R., Calderón, J. E. Z., \& Suárez, C. E. C. (2019). Diseños de investigación. Educación y Salud Boletín Científico Instituto de Ciencias de la Salud Universidad Autónoma del Estado de Hidalgo, 8(15), 119-122.

4. Decreto 622. (1977). https://www.cvc.gov.co/sites/default/files/2018-10/Decreto\%20622\%20de\%201977-Mar-16.pdf

5. Decreto

2811.

(1974).

https://www.minambiente.gov.co/images/GestionIntegraldelRecursoHidrico/pdf/normativa/Decreto 2811 de 1974.pdf

6. EOT. Esquema de Ordenamiento Territorial. (2001). Acuerdo Esquema de Ordenamiento municipio de San Juanito. Esquema de Ordenamiento Territorial. http://cdim.esap.edu.co/BancoConocimiento/S/san_juanito___meta___eot___2001/san_juanito__meta__eot_-_2001.asp.

7. Fernández-Zamudio, M., Caballero, P. \& De Miguel, M. (2006). La gestión del minifundio a través de las cooperativas en la Comunidad Valenciana. CIRIEC-España, Revista de Economía Pública, Social y Cooperativa (55), 193-219.

8. IGAC. Instituto Geográfico Agustín Codazzi. (2013). Mapa territorios San Juanito. https://www.igac.gov.col

9. Mendigorri, A. M. (2017). Territorio y áreas protegidas en España y Portugal: dos modelos de intervención en una geografía compartida. Boletín de la Asociación de Geógrafos Españoles, (74).

10. Olea-Peñaloza, J. (2017). Latifundio y territorio: reflexiones en torno a la reforma agraria en Colchagua, 1960-1973 POLIS, Revista Latino Americana, 16 (47), 83-106.

11. Orgaz-Agüera, F. (2018). Modelo para Establecer Estrategias que Fomenten la Economía Social de las Comunidades Rurales en Áreas Naturales Protegidas en la República Dominicana/Model to Establish Strategies that Foster Social Economy of Rural Communities in Natural Areas Protected in the Dominican Republic. ROSA DOS VENTOS-Turismo $e$ Hospitalidade, 10(4).

12. PNN. (2017). Plan estratégico y de manejo del Parque Nacional Natural de Chingaza 2016-2020. Parques Nacionales Naturales. Bogotá D.C. (Colombia) 
13. Parques Nacionales Naturales de Colombia. Áreas Protegidas: Territorios para la Vida y la Paz. Tomo I: Áreas protegidas para el desarrollo. 2015, Retrieved from http://www.parquesnacionales.gov.co/portal/wpcontent/uploads/2015/11/PNNC_TOMO1_VF2.pdf

14. Ponce de León Chaux, E. (2019). Estudio jurídico sobre categorías regionales de áreas protegidas. Instituto Von humbot.

15. Rauch-González, M., Catalán-Martina, E., Aguilera-Bascur, G., Valenzuela-Vergara, I., Maldonado-Osorio, S., \& MartínezPalma, P. (2019). Gestión intercultural para la conservación en Áreas Silvestres Protegidas del Estado: aprendizajes y desafíos. Revista Austral de Ciencias Sociales, (35), 183-204. doi:10.4206/rev.austral.cienc.soc.2018.n35-11

16. Resolución 710 (2016). https://www.ambienteysociedad.org.co/resolucion-0710-de-2016-que-delimita-el-paramo-dechingazal

17. Resolución 154(1977). http://www.parquesnacionales.gov.co/portal/es/normatividad/marco-normativo-areasprotegidas/parque-nacional-natural-chingazal

18. SIG Unillanos (2017) Sistema de Información Geográfica de la Universidad de los Llanos. Villavicencio (Meta) Colombia

19. Vásquez M, J. L., \& Andrade, G. I. El paisaje protegido, pieza faltante en el Sistema de Áreas Protegidas de Colombia Resumen. Biodiversidad En La Práctica Documentos de Trabajo Del Instituto Humboldt, 2016, 1(2015), pp,128-146.

20. Vergara-Pinto, F., \& Campos Albornoz, N. (2019). Aciertos y desafíos del Paisaje de Conservación Valle Río San Pedro: Desarrollo local y conservación de la naturaleza en el sur de Chile (Provincia de Valdivia) / Successes and Challenges of the San Pedro River Valley Conservation Landscape: Local Development and Nature Conservation in Southern Chile. Estudios del Desarrollo Social: Cuba y América Latina, 7. Recuperado de http://www.revflacso.uh.cu/index.php/EDS/article/view/349 